\title{
GREEN SUPPLY CHAIN MANAGEMENT AND TRENDS IN LOGISTICS: CURRENT PRACTICES IN TURKEY
}

\author{
Gül Esin DELIPINAR ${ }^{1}$, Celil DURDAĞ $\breve{G}^{2}$
}

\begin{abstract}
Increase in population and development in industry and technology have a great impact on consumption. Increase in the consumption leads to environmental pollution and global warming eventually. These threats have taught people to be sensitive to the environment and to live 'green' while trying to make life easier for themselves. For this reason, the production, distribution and marketing of the product have emerged under the concept of 'green supply chain management' as an environmentally friendly study. In Turkey, industrialization process did not have an intention to give harm to environment. Therefore, green practices are started to be used in the production and services today in our country. For this reason, the subject of "Green Supply Chain Management" has been chosen and tried to be explained in order to primarily guide all domestic and foreign businesses operating in our country to improve their environmental performance by reducing their environmental impacts. The first part of the study is a review on green supply chain management and mentions the usages in logistics. The latter part of the study aimed to shed light on the green logistics applications to the companies in Turkey by comparing the existing applications with the literature, and with in the content analysis.
\end{abstract}

It is also tried to reach the opinions of the logistics sector representatives about the perception of green supply chain management and Turkey's situation on this issue. In addition, the study also discusses what can be done for the future in terms of the environment.

Keywords: Green Supply Chain Management, Sustainability, Environment, International Trade

JEL Classification: F18, L91, R41, Q01.

\section{YEŞIL TEDARIKK ZINCİRİ YÖNETIMİ VE LOJISTIKTE EĞİLIMLER: TÜRKIYY'DE MEVCUT UYGULAMALAR}

$\ddot{O} \mathbf{z}$

Nüfusun artması, sanayi ve teknolojinin gelişmesi tüketim üzerinde büyük etkiye sahiptir. Tüketimin artması nihayetinde çevre kirliliğine ve küresel ısınmaya yol açmaktadır. Bu tehditler insanlara çevreye duyarlı olmayı ve kendileri için hayatı kolaylaştırmaya çalışırken 'yeşil' yaşamayı ögretmiştir. Bu nedenle ürünün üretimi, dağıtımı ve pazarlanması çevre dostu bir uygulama olarak 'yeşil tedarik zinciri yönetimi' kavramı altında ortaya çıkmıştır. Buna karşın Türkiye'de sanayileşme süreci çevreyi hesaba katmamış ve istemeden çevreye zarar vermiştir. Ancak günümüzde ülkemizde de üretim ve hizmetlerde yeşil uygulamalar kullanılmaya başlanmıştır. Bu nedenle çalışmada öncelikle ülkemizde faaliyet gösteren tüm yerli ve yabancı işletmelere çevresel etkilerini azaltarak çevresel performanslarını iyileştirmeleri konusunda rehberlik etmek amacıyla "Yeşil Tedarik Zinciri Yönetimi" konusu seçilmiş ve açıklanmaya çalışılmıştır. Bu çalışmanın ilk bölümleri, yeşil tedarik zinciri yönetimi üzerine bir inceleme olup lojistikteki kullanımlarından bahsetmektedir. Sonraki bölümlerde mevcut uygulamalar literatür ile karşılaştııılarak yeşil lojistik uygulamalarının Türkiye'deki firmalara ışık tutmassı amaçlanırken yapılan içerik analiziyle beraber lojistik sektör temsilcilerinin yeşil tedarik zinciri yönetimi algısı ve Türkiye'nin bu konudaki durumu hakkında görüşlerine ulaşılmaya çalışılmaktadır. Ayrıca çalışma çevre açısından gelecek için neler yapılabileceğini de tartışmaktadır.

${ }^{1}$ Dr. Öğr. Görevlisi, Yeditepe University, edelpnar@ yahoo.com, ORCID: 0000-0001-5402-708X

${ }^{2}$ Dr. Öğr. Üyesi, İstanbul Esenyurt Üniversitesi Lojistik Yönetimi, celildurdag@esenyurt.edu.tr. ORCID: 0000-0002-7323-2190 
Anahtar Kelimeler: Yeşil Tedarik Zinciri Yönetimi, Sürdürülebilirlik, Çevre, Uluslararası Ticaret

JEL Sinıflaması: F18, L91, R41, Q01.

\section{Introduction}

The production facilities' wastes have caused environmental pollution and this situation has reached a dimension that threatens human life as well as all living things. Pollution eventually damages the ecosystem. Environmental problems are today's one of the most important problems and considering the environment at every stage of today's supply chain management has become a requirement now. In line with this requirement, all members of the supply chain have started to adopt the principle of green principle with both willingly and necessarily (Acer \& Karagöz- Taşkın, 2020). The concept of "Green Supply Chain Management" has come out with the idea of reducing the environmental impacts of the supply chain. Moreover, although green products are more expensive than non-green products in developed countries, the willingness of environmentally conscious customers to pay more for them is a motivation in understanding of green supply chain management (Shetty \& Bhat, 2022).

Green supply chain management (GSCM) is described as "integrating environmental thinking into supply chain management, including product design, material procurement and selection, manufacturing processes distribution of the final product to customers, and end-of-life management of the product after its useful life" (Srivastava, 2007). Green supply chain management not only aims to increase the company performance, but also supports environmental problems.

Environmental problems experienced in recent years have led to the rapid development of environmental awareness of societies and various groups, customers, competitors and stakeholders, and forces businesses to increase their environmental activities. It seems like; environmental problems will also continue to be discussed in the future. Therefore, it is valuable to mention the green supply chain management of different industries in Turkey.

The need to switch from supply chain management to the green supply chain management is stemmed from the following reasons:

- Changes in ecosystem

- Customer demands

- $\quad$ Increased competition among companies

- $\quad$ Competitive advantage

- $\quad$ Need for cost reduction

- $\quad$ Stakeholder demands

- Company policies

- $\quad$ Consumer awareness

- Sustainability of environment (Zhu et al., 2012), (Ying, \& Li-jun, 2012), (Kushwaha, 2010), (Gupta \& Palsule-Desai, 2011). 
This study starts with the literature review on green supply chain management and trends in logistics, and then it continues with the current practices of companies in Turkey.

After, with the content analysis, the perception of the logistics side will be revealed, and it will shed light on future research.

\section{Literature Review on Green Supply Chain Management and Trends in Logistics}

Green supply chain practices have the following phases: (Srivastava, 2007).

\subsection{Green Purchasing}

According to the changing trends, manufacturers need to buy the necessary products not only considering the quality and affordable prices of materials but also need to consider the environmental impact of its suppliers and their products. In the literature, green purchasing is defined as, purchasing the products among the return of recyclable, reusable, or recycled materials for use in production. Green purchasing often includes recycled content, energy efficiency and waste reduction. The green purchasing creates competitive advantage, and it has a positive impact on firm performance (Khan \& Qianli, 2017).

\subsection{Green Design}

The aim of green design is to reduce the negative environmental impact of products to ensure that it is produced using appropriate materials and technologies. It is expected that manufacturers use environmentally friendly materials both in the production process and in the end user. Eventually, design of product will reduce the negative environmental effects. Therefore, use of raw materials with less environmental impact is essential to require less energy, and energy efficiency is needed for sustainability. When the products are designed to be durable, it will have more quality and will be used for a long time, which will decrease consumption. Reusable/Recyclable products can also create value added production and reduce carbon footprint. (Fortes, 2009).

\subsection{Reverse Logistics}

Reverse logistics includes activities such as reduce, reuse, remanufacture, and recycle. (waste, cans, bottles, paper, etc.). In addition to these, the resale of returned or defective products in different sales channels can also be considered within the scope of reverse logistics. Therefore, reverse logistics can be defined as environmentally logistics activities that increase environmental efficiency and are redesigned to manage the flow of products or parts in order to use resources effectively (Carter \& Ellram, 1998).

\subsection{Green Manufacturing}

Bu çalışma, Esenyurt Üniversitesi Bilimsel Araştırma ve Yayın Etiği Kurulunun 23/12/2021 tarihli ve 2021/11 sayılı toplantısında alınan karar ile Araştırma ve Yayın Etiğine uygun bulunmuştur. 
Green manufacturing focuses on environmentally friendly production processes and profitability strategy. The waste management while creating environmentally friendly production processes may increase profitability.

Green production processes basically reduce the waste generation during production. However, it is not enough to reduce waste alone, in addition to it; emissions and wastewater also need be reduced.

Additionally, reducing the use of resources is also essential. In the production, reducing the raw materials required for production and renewable energy is crucial. Today, natural resources are consumed rapidly. Therefore, green production processes are important to mention (Paul et al., 2014).

\subsection{Green Packaging}

One of the Green Supply Chain applications is green packaging. Green packaging is the general reduction of packaging processes and the materials used. In addition to material reduction, the use of recycled materials instead of plastic materials is a requirement of green packaging practice. Green packaging is the packaging that can be reused, recycled and which does not cause pollution in humans and the environment during the product life cycle (Zhang \& Zhao, 2012).

\subsection{Waste Management}

The green supply chain management practices can increase the performance of the company and environmental sustainability can be achieved by with the reduction in air emissions, waste and toxic materials (Green et al., 2012).

\section{Current Practices of Companies in Turkey}

Green logistics is a new managerial approach that combines product development and environmentally friendly product/service production strategies. Green logistics activities are needed in order to produce, purchase and distribute products and services to be environmentally friendly, to recycle and reuse products that have expired, and to resell returned or defective products in different sales channels. Green logistics practices reduce difficulties in all decisions in the business process, strengthen the control mechanism, enable recycling and enable more efficient resource use (Yangınlar \& Sarı, 2014).

The initiator and first implementer of green activities in Turkey was the government, as in many other areas. In 2009, Turkish Parliament adopted the Kyoto Protocol, which aims to reduce the greenhouse gas concentration in the atmosphere. In accordance with the adoption of this protocol, SCT rate reductions were made in order to withdraw old model vehicles from traffic in road transport.

After the government has an emphasis on green supply chain management practices, the companies that received logistics service first started green supply chain practices. Migros, for example, one of the few chain markets in Turkey, has focused on the use of recycled packaging in order to reduce carbon emissions and not pollute the environment. It has also reduced its paper-based operations with the virtual market application. 
Likewise, Arçelik company has also focused on recycling in packaging to combat global warming. In addition, Arçelik wants its transportation operations to be carried out by sea and rail, not by road (Desticioğlu, 2021).

For air transport, the addition of aircraft that emit less carbon to the fleet was encouraged. In order to prevent the companies which will operate at the airports, from harming the environment, it was aimed to encourage the companies by introducing the title of "Green Organization". Finally, in October 2021, our state became a party to the Paris Climate Agreement. Clearly, this agreement can bring many new regulations for supply chains.

Today, the competition of companies takes place not only between the products they produce, but also between the logistics strategies they use. The fierce competition that has occurred recently, the pressure of environmental non-governmental organizations, the increase in customers' preferences for green products and green processes has led businesses to reorganize their logistics strategies.

Environmental protection, remanufacturing and recycling and cost reduction, social responsibility, legal and customer pressures increase green logistics activities by creating pressure on businesses. These pressures have motivating effects on businesses to continue their green logistics practices. Green logistics practices of enterprises reduce the cost of raw material and material acquisition, fulfill their social responsibility task and improve the image of environmentally friendly firms (Yangınlar \& Sarı, 2017).

Some shipping companies in Turkey had a mission to lower their carbon emissions level. It can be easily said that the first applications of companies providing logistics services within the scope of green logistics in Turkey; are carried out in the form of shifting towards more environmentally friendly modes in transportation systems and preferring intermodal transportation by moving away from road-based transportation.

Again some shipping companies in Turkey has a mission of creating warehouses which use solar energy. It also aims to use recycled rainwater. Additionally, the building will have improved insulation which will save energy. Similar examples are available abroad which is possible to benchmark.

Turkish companies, which use highway travelling to Europe, equip their fleets with Euro 6 motor vehicles and benefit from the highway and other tax reductions that Europe provides to companies using state-of-the-art technology as well as environmentally friendly companies.

Green logistics activities in Turkey have also shown their effect in urban logistics. Since it is known that traffic congestion increases fuel consumption and causes air pollution, urban logistics actors have tried to provide the shortest way with vehicle routing applications. A similar goal is pursued with night deliveries. Encouraging customers to pick up their purchases from certain delivery points also helps urban logistics actors to reduce their carbon footprints.

Although there are not many examples in our country currently, developed countries are also using drone to deliver products as an example of green logistics activities. 


\section{Research Methodology}

\subsection{Sample and In-depth Interview Method}

This study was applied in the Turkish branch of a large global logistics company in Istanbul, using in-depth interview technique, which is one of the qualitative research techniques.

The sample group of eight participants consists of those responsible for the import-export operations of the company with different transportation modes. It has been determined that the interviewees participating in the study have majors in engineering, business and logistics.

Since the aim of the study is to reveal the perspectives of those interviewees for the green supply chain management approach and what they think about the practices carried out in this field in our country, the employees of a company that has signed these practices on a global and local scale were included in the research. Each interview lasted an average of 60 minutes. Voice recordings and notes were taken during the interviews with the permission of the interviewees. The interviews were arranged by the article authors at separate times.

By asking questions "What are your thoughts on green supply chain management?" and "What do you think about green supply chain practices in Turkey?" which will keep the two intervieews in the form of the interview. In the context of it, the atmosphere was created for the interviewees to convey their ideas easily.

\subsection{Content Analysis and Findings}

Content analysis method was used to analyze the data collected as a result of in-depth interviews. The main purpose of using the content analysis method is to reveal the fact that the collected data make sense conceptually and relationally. The basic idea in content analysis is to bring similar data together, to classify them under the same concepts and themes, and finally to convey the result in a way that readers can fully understand (Yıldırım \& Şimşek, 2011).

In content analysis, firstly, the data is divided into meaningful parts. Then, these meaningful parts are defined conceptually and certain codes are assigned to facilitate the arrangement of these words according to their subjects. After the coding is completed, these codes are categorized according to their similarities or differences. Accordingly, similar ones are grouped under the same category. Coding and categorization make content analysis rich and systematic.

In this study, codes were given according to the words used by the interviewees in their speeches on the subject, and words that were similar to each other were put under the same category. When the answers they gave to the question, "What are your thoughts on green supply chain management?", were evaluated, it was determined that a significant part of them called it environmentally friendly activities. Another frequently repeated expression is social responsibility.

"What do you think about green supply chain practices in Turkey?". In this question, the most repeated words among the answers given by the responsible people are shown in Table 1 below: 
Table 1: The most repeated words, respectively, about green supply chain practices in Turkey

\begin{tabular}{|l|}
\hline $\begin{array}{l}\text { The Most Repeated Words, Respectively, About Green Supply Chain Practices in } \\
\text { Turkey }\end{array}$ \\
\hline 1. Recycled Packaging \\
\hline 2. Waste Management \\
\hline 3. Reverse Logistics \\
\hline 4. Vehicle Routing \\
\hline 5. Consolidation \\
\hline 6. Intelligent Robot Automation Systems \\
\hline 7. Cloud Solutions \\
\hline
\end{tabular}

When the answers given to the question, "What do you think about green supply chain practices in Turkey?", are examined, it is remarkable that smart robot automation systems and cloud solutions, which are among the elements of industry 4.0, are evaluated within green supply chain applications in Turkey.

The belief that it is possible to easily associate the data to be stored in the system with green activities is shared by the people who are responsible. When this issue was reminded to those interviewees, it was thought that the environment would be positively affected by the decrease in the number of humans used in the works with automation.

In answers to the question, "Does green supply chain management increase operating costs?", it was emphasized that some costs of companies may increase until they adapt to this understanding, but there will be a cost reduction when sustainability is ensured in the medium and long term. In the answers given to the question, "Does green supply chain management provide a competitive advantage to the business?", it is noticed that interviewees did not agree on the answers. Some of them thought that a competitive advantage would be achieved with green supply chain management, while the other part stated that nothing would change by making an evaluation especially in Turkey.

Finally, in the answers given to the question, "Are green supply chain practices sufficient in Turkey?", all interviewees answered and thought that the green supply chain practices are not sufficient. Almost all of the interviewees emphasized that there is a serious lack of awareness about green supply chain practices in our country.

In the light of all these findings, the opinions of the interviewees are summarized under two main categories according to the content analysis and with the codes stated below as in Table 2

Table 2: Content Analysis Table

\begin{tabular}{|l|l|l|}
\hline \multirow{4}{*}{ THEME } & \multicolumn{3}{|l|}{$\begin{array}{l}\text { Opinions of Import and Export Responsible on Green } \\
\text { Supply Chain and Turkey Practices }\end{array}$} \\
\hline \multirow{5}{*}{ Categories } & $\begin{array}{l}\text { Opinions on the Green } \\
\text { Supply Chain }\end{array}$ & $\begin{array}{l}\text { Opinions on Turkey } \\
\text { Practices }\end{array}$ \\
\hline & Respect for Environment & Lack of awareness \\
\cline { 2 - 3 } Codes & Social Responsibility & Lack of Implementation \\
\cline { 2 - 3 } & Sustainability & Focus on Consolidation \\
\cline { 2 - 3 } & Competitive advantage & $\begin{array}{l}\text { Focus on Waste and } \\
\text { Packaging }\end{array}$ \\
\hline
\end{tabular}




\section{Conclusion}

It is certain that logistics service providers will not stay away from green transformation in an environment where the global climate crisis has entered our lives day by day, and governments are no longer neutral to this crisis and sign agreements that will save the world.

No matter what level the logistics activities are carried out, they can give the potential harm to the environment. Besides the air and noise pollution of the vehicles used in logistics services, an important part of the handling activities, which are considered as value-added services within the logistics services, cause the emergence of wastes from various materials. The longer the supply chain and international trade continues, the greater the level of pollution and waste material generated.

If logistics service providers want to continue their activities without further legal restrictions and social pressure in the future, they should start green supply chain practices as soon as possible.

In Turkey, it is obvious that some companies that are candidates for being a fourth party logistics company need to make their customers adopt green sensitivity as an approach that it is not possible for each company to achieve the desired total benefit by doing it by itself. It should be noted for sure that this maturity must first be in the logistics service provider company. Every actor in the entire supply chain must do its own responsibility for green practices.

Although the study is raising awareness, the biggest limitation of the study is; while a company that performs green supply chain management on a global and local scale makes evaluations on its employees, it disregards other logistics companies or companies that receive logistics services' employee perspectives. Future research might study the perspective of the same topic within different companies. Another future research might be on how the actors in the supply chain view the green supply chain. Another study which can be beneficial for the literature might be on the similarities and differences which are revealed by selecting a specific company or green supply chain practices in the world and in Turkey.

\section{References}

Acer, A.; Karagöz-Taşkın, İ. B. (2020). Çevreye Duyarlı ve Yeşil Tüketici: Üniversite Öğrencilerine Yönelik Bir Araştırma, Ömer Halisdemir Üniversitesi İktisadi ve İdari Bilimler Fakültesi Dergisi, 13(2), pp.260-276.

Carter, C. R.; Ellram L. M. (1998). Reverse logistics: A review of the literature and framework for future investigation, Journal of Business Logistics, 19, 85-102.

Desticioğlu, B. (2021). Green Supply Chain Managemet And Sample Applications, Journal of Naval Sciences and Engineering, 17(2), 283-308.

Fortes, J. (2009). Green supply chain management: A literature. Otago Management Graduate Review, 7(1), 51-62.

Green J. K. W., Zelbst, P. J., Meacham, J.; Bhadauria, V. S. (2012). Green supply chain management practices: impact on performance, Supply Chain Management: An International Journal, 17, 290 - 305.

Gupta, S.; Palsule-Desai, O. D. (2011). Sustainable supply chain management: Review and research opportunities. IIMB Management review, 23(4), 234-245. 
Khan, S. A. R.; Qianli, D. (2017). Impact of green supply chain management practices on firms' performance: an empirical study from the perspective of Pakistan. Environmental Science and Pollution Research, 24(20), 16829-16844.

Kushwaha, G. S. (2010). Sustainable development through strategic green supply chain management. International Journal of Engineering and Management Science, 1(1), pp.7-11.

Paul, I. D., Bhole, G. P., Chaudhari, J. R. (2014). A review on green manufacturing: it's important, methodology and its application. Procedia materials science, 6, 1644-1649.

Shetty, K, S.; Bhat, S, K. (2022). Green supply chain management practices implementation and sustainability -A review, Materials Today: Proceedings, $\mathrm{x}(\mathrm{x}), 1-6$.

Srivastava, S. (2007). Green supply-chain management: A state-of-the-art literature review. International Journal of Management Reviews, 9(1), 53-80.

Yangınlar, G.; Sarı, K. (2014). Yeşil Lojistik Uygulamaları ve İşletme Performansı Üzerine Bir Literatür Araştırması, III. Ulusal Lojistik ve Tedarik Zinciri Kongresi, 15-17 Mayıs 2014, Trabzon.

Yangınlar, G.; Sarı, K. (2017). İşletmeleri Yeşil Lojistik Uygulamalarına Zorlayan Sebepler Üzerine Bir Araştırma, Trakya Üniversitesi İktisadi ve İdari Bilimler Fakültesi EDergi, 6(1), 101-121.

Yıldırım, A.; Şimşek, H. (2011). Sosyal Bilimlerde Nitel Araştırma Yöntemleri, Ankara: Sekin.

Ying, J.; Li-jun, Z. (2012). Study on green supply chain management based on circular economy. Physics Procedia, 25, 1682-1688.

Zhang, G.; Zhao, Z. (2012). Green packaging management of logistics enterprises. Physics Procedia, 24, 900-905.

Zhu, Q.; Sarkis, J.; Lai, K. H. (2012). Green supply chain management innovation diffusion and its relationship to organizational improvement: An ecological modernization perspective. Journal of Engineering and Technology Management, 29(1), 168-185.

Bu çalışma, Esenyurt Üniversitesi Bilimsel Araştırma ve Yayın Etiği Kurulunun 23/12/2021 tarihli ve 2021/11 sayılı toplantısında alınan karar ile Araştırma ve Yayın Etiğine uygun bulunmuştur. 